Research Paper

\title{
Attention Deficit Hyperactivity Disorder in Preschool Age: Lived Experiences of Mothers
}

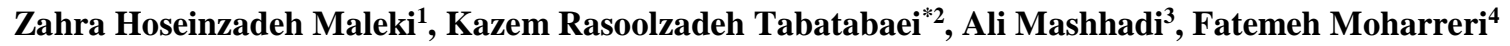 \\ 1. Ph.D. Student of Psychology, Faculty of Humanities, Tarbiat Modares University, Tehran, Iran \\ 2. Associate Professor, Department of Psychology, Faculty of Humanities, Tarbiat Modares University, Tehran, Iran \\ 3. Associate Professor, Department of Psychology, Faculty of Educational Sciences and Psychology, Ferdowsi University of \\ Mashhad , Iran \\ 4. Associate Professor, Department of Psychiatry and Behavioral Sciences Research Center, Mashhad University of Medical \\ Sciences, Iran
}

Accepted: October 4, 2018

\begin{abstract}
Background and Purpose: Mothers are the most important factors in the prognosis of attention deficit hyperactivity disorder in pre-school children. Detecting mothers' experiences in daily life increases the potential of improving the effects of interventions on the child and enhancing the parents' level of well being. Therefore, the purpose of the present study was to explore Iranian mothers' experiences in raising preschool children with attention deficit hyperactivity disorder.

Method: This research was executed in the qualitative method of phenomenological approach throughout a period of four months in 2016. The statistical population consisted of mothers who had preschool children with attention deficit hyperactivity disorder who referred to Ebne-Sina Psychiatric Clinic in Mashhad. Through convenient sampling which continued until saturation, 15 mothers were selected and participated in an unstructured in-depth interview. The interviews were analyzed with Colaizzi's method.

Results: Mothers' experience was categorized into three main domains. "Inadequacy of knowledge" consisted of mothers' unfamiliarity with the diagnosis, and the inaccessibility of scientific resources and applied knowledge. The "difficulties of treatment" displayed their experience to manage the disorder focused on the limitations of treatment systems and the challenges of pharmacotherapy. "Interaction problems in social network" signified the tension, conflict, guilt and shame, and loneliness and isolation brought on by child's disorder.

Conclusion: Raising children with ADHD is a difficult experience which requires mothers' professional support throughout the early years of the disorder's development. Therefore, all of the findings of the present study are potential treatment goals in increasing mothers' well-being and they can be used to improve existing interventions and design new ones.
\end{abstract}

Keyword: Preschool, attention deficit hyperactivity disorder, lived experiences

Citation: Hoseinzadeh Maleki Z, Rasoolzadeh Tabatabaei K, Mashhadi A, Moharreri F. Attention deficit hyperactivity disorder in preschool age: lived experiences of mothers. Quarterly Journal of Child Mental Health. 2019; 6(1): 265-275.

*Corresponding author: Kazem Rasoolzadeh Tabatabaei, Associate Professor, Department of Psychology, Faculty of Humanities, Tarbiat Modares University, Tehran, Iran.

Email: Rasoolza@modares.ac.ir $\quad$ Tel: (+98) 21-82880000 


\title{
اختلال نارسايى توجه /فزون كنشى در سنين يِشدبستان: تجارب زيسته مادران
}

\author{
زهرا حسين زاده ملكى'، كاظم رسول زاده طباطبايى"، على مشهدى"، فاطمه محررى \\ ا. دانشجوى دكتراى تخصصى روانشناسى، دانشكده علوم انسانى، دانشگاه تربيت مدرس، تهران، ايران

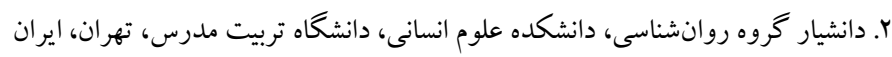

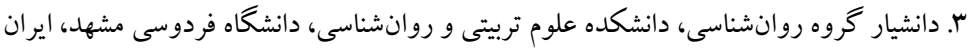

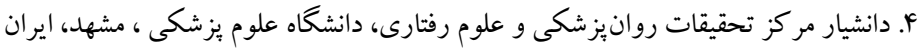

تاريخ بذيرش:

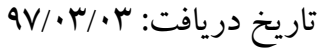

زمينه و هدف: مادران طى سالهاى ييشدبستان، مهم ترين عامل مؤثر بر ييش آكهى اختلال نارسايى توجه/فزون كنشى كود كان هستند.

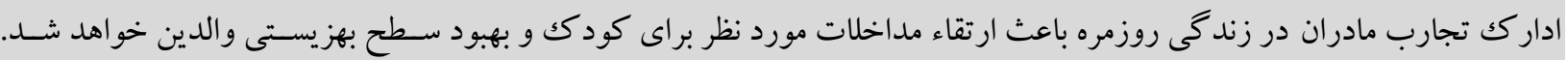

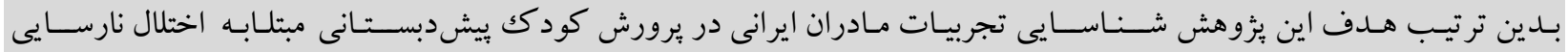
توجه /فزون كنشى بود.

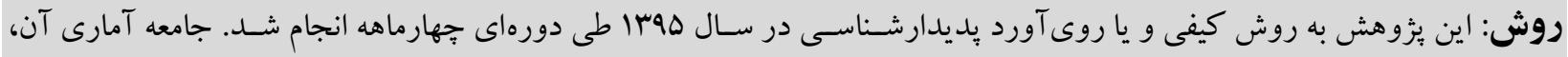

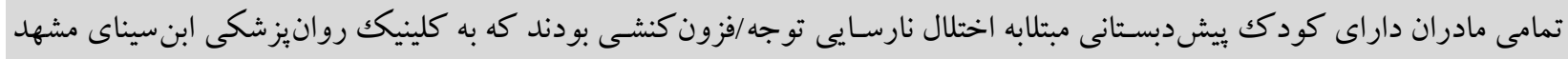

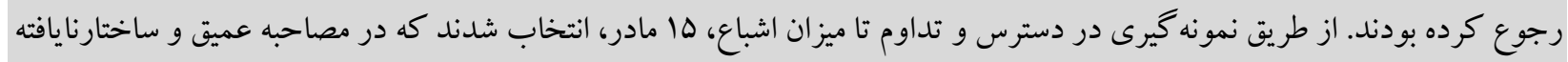

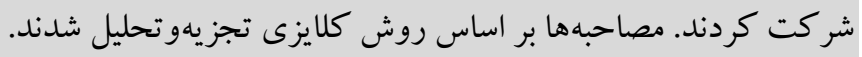
يافتهها: تجارب مادران در سـه مضـمون اصـلى سـازمان يافت: نابسـدكى دانش و آكاهى، دشـوارىهاى درمان، و مشكلات تعامل در شبكه اجتماعى. اين سه مضمون اصلى در مقاله به تفصيل مورد بحث قرار كرفتند.

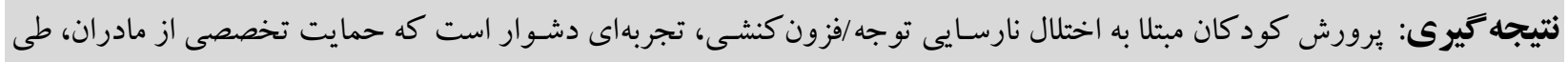

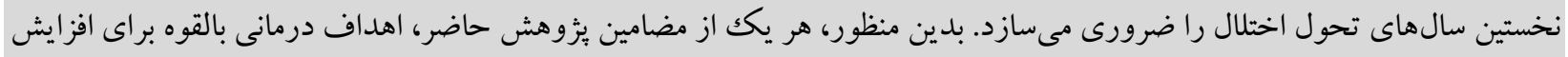

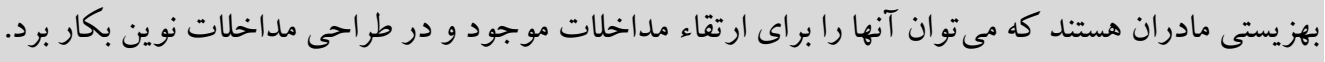
كليدوازهها: بيشدبستانى، اختلال نارسايى توجه فزون كنشى، تجارب زيسته

*نويسنده مسئول: كاظم رسول زاده طباطبيى، دانشيار گروه روانشناسى، دانشكده علوم انسانى، دانشكاه تربيت مدرس، تهران، ايران. 
و تعاملهاى والد-كود كـ را تضــعيف سـاخته، و در نتيجه،

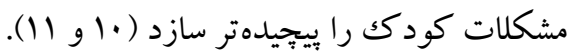

در ســالهـاى اخير، بهبود نتايج درمانى از طريق توجه به

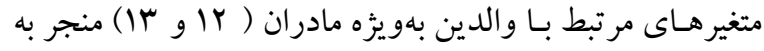

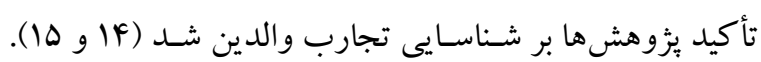

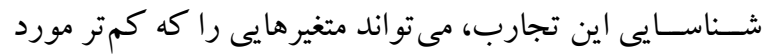
توجه متخصصين بوده و به تأثيرات والدين طى زند بـى روزمره

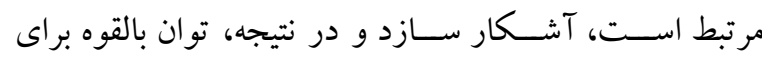
اثربخشى مداخلات را افزايش دهد (19).

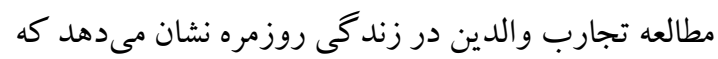

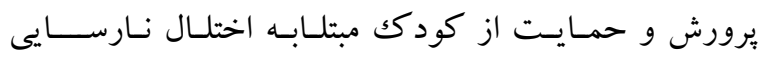
توجه/فزون كنشـى تجربهاى دشـوار اسـت (Vا و IN). در اين

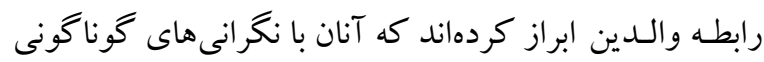

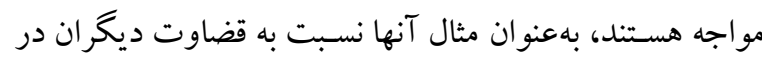
مورد كودك و بهطور كلى تأثيرات اختلال بر آينده فرزندشـان

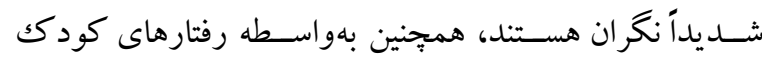

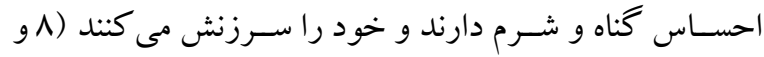

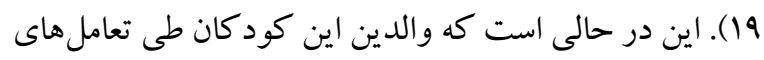
روزمره، به دليل وجود نشانها و ييامدهاى اختلال در كودكى، بـا واكنشهـاى منفى افراد جامعه و حتى خانو اده خود مواجه

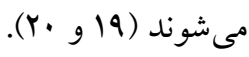
هرجند بخشى از تجارب منفى والدين به ارتباط با سايرين

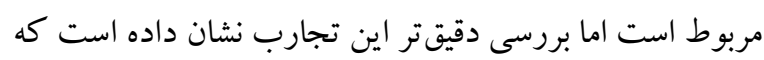
والدين نيز آكاهى محدودى نسبت به اين اختلال خصسوصاً در

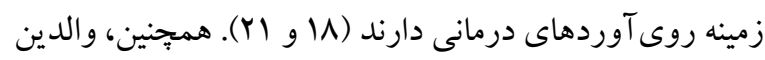
توصسيه هاى متخصصين را در مواردى، مفيد مىداند اما ممكن

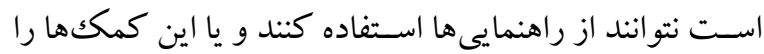
ناكافى توصسيف كنند (1))؛ بنابر اين با مرور تجارب والدين

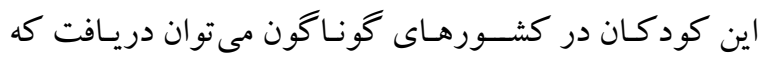

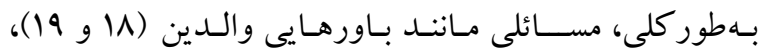

3. Conduct Disorder (CD)

\section{مقدمه} كود كان مبتلابه اختلال نارسايى توجه فزون كنشى' غالباً تا ييش

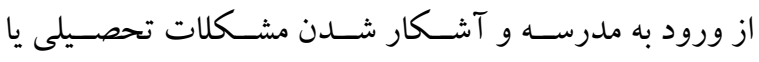
ييجيجيدهر شـدن ساير يِيامدهاى اختلال، شناسايى نمى شوند، در

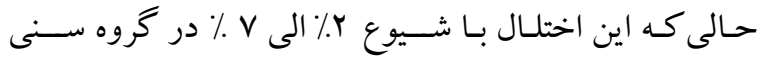
بيشدبستان، بسيار رايج است و ابتلا به آن در سالهاى نخستين زندكى، مى تواند به مشـكلات تحولى و عملكردى در سـراسـر

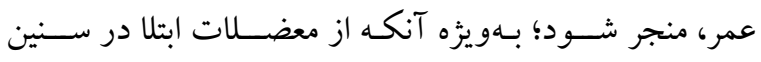
يّيش دبسـتان، همبودى بسـيار بالاى اين اختلال با اختلالهاى

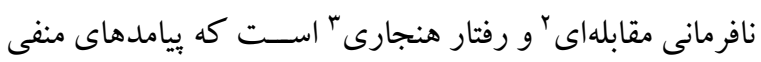

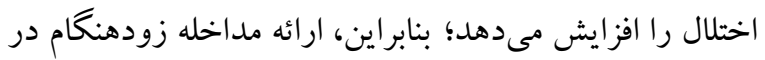

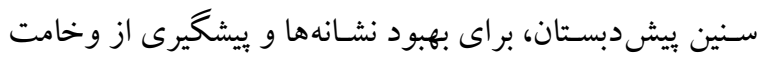

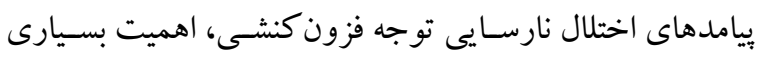

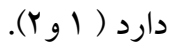

به منظور ارائه مؤثرترين مداخلات، بثروهشـــران بو بيامدهاى اين اختلـال را مورد مطالعه دقيقترى قرار داده و دريافتهاند كه مركه دامنه اين بيامدهاى تحولى بسيار متغير اسـت (1) در تبيين اين

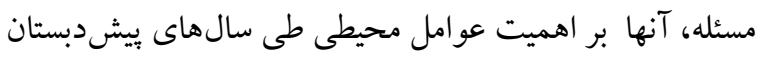

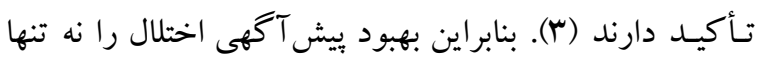
منوط به مداخله در سـنين ييشدبسـتان، كه با تمركز بر عوامل محيطى در اين سنين مىدانند (F)

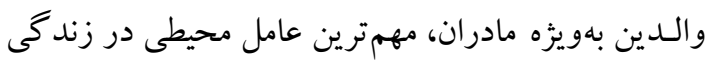

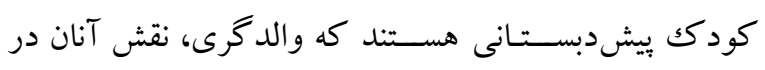
تشـخيص، ارجاع و درمان كودك،، بر سـير اختلال مؤثر اسـت. در واقع يزووهشهاى فراوانى نشـان دادهاند كه شدت نشانهها و وخدي وخامت بيامدها با متغيرهاى مر تبط با والد، مانند ســلامت روان

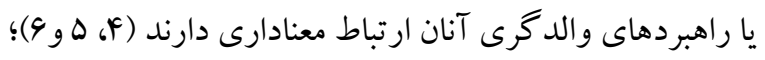

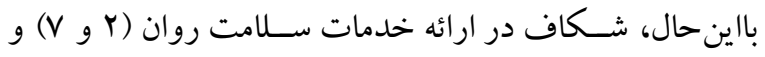
مشكلات زندكى با اين كود كان، بر بهزيستى والدين تأثيرات

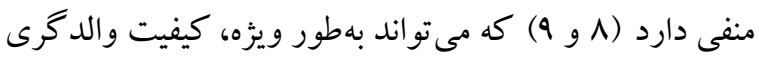


روش

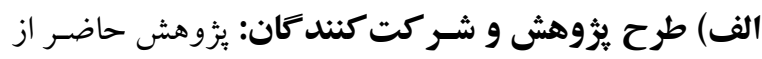
نوع يزوهشهـاى كيفى اسـت كـه با اســفاده از روى آورد يديدارشـناسى انجام شده است. با توجه به موضوع اين مطالعه، يُزوهش كيفى كه داراى روشــى نظاممند و ذهنى اســت براى توصسيف تجـارب زنـدگى و درك معسانى آن كـارايى دارد.

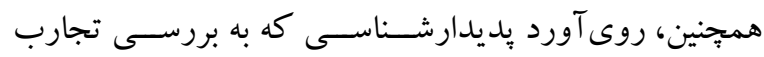

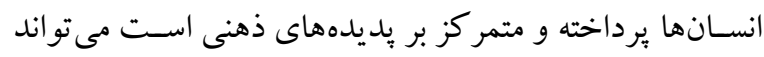

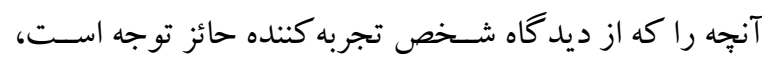

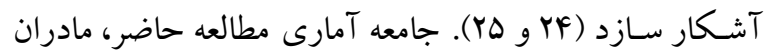

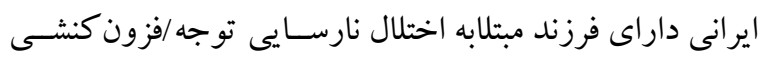
ييش دبستانى در سال هوس| بودند كه با مراجعه به كلينيك ويثز

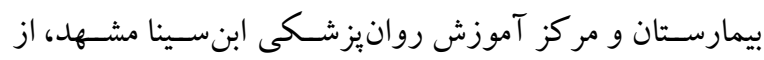

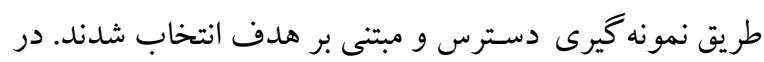

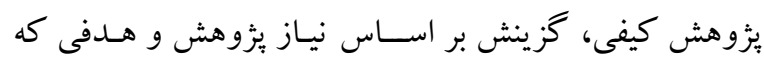

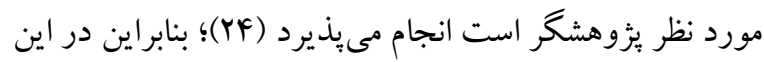

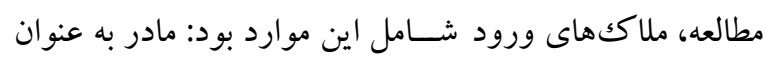
مر اقب اصلى و مادر بيولوزيكك كودكك بيشدبستانى (F الى 9

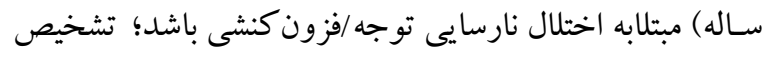
اختلال حداقل سه ماه ييش از مشاركت در مطالعه، توسط فوق تخصص روانيزشكى كودك و نوجوان، صورت گرفته باشد؛ مادران بايد آمادكى اشـتر اكى گذارى و توانيى بيان واضـح

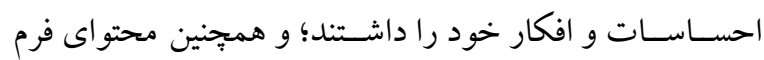
رضايت آكاهانه را امضا مى كردند. ملاككهاى خروج از مطالعه

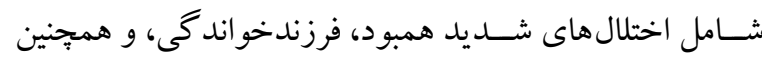
طلاق والدين بود. بهطور كلى در اين شيوه، زمانى كه مصاحبهها حاوى اطلاعات جديد و متفاوت با مصاحبه هاى بيشين نباشند،

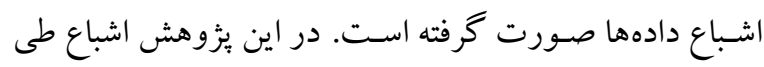
مصاحبه با تعداد ها مادر حاصل شد.

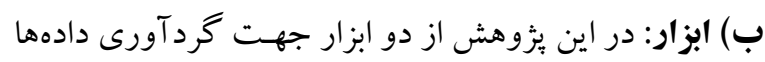

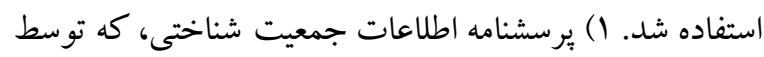
يُزوهشـر سـاختهشـده و شامل اطلاعات جمعيت شناختى ماند
بى توجهى متخصسـين به نيازهاى والدين، و وجود تعارضـات

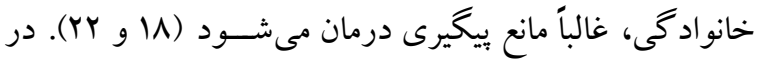

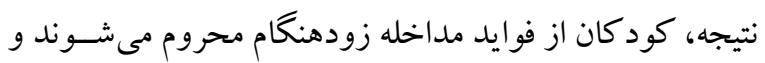

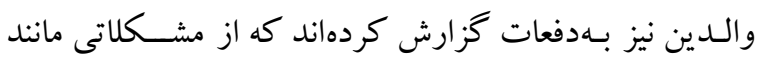

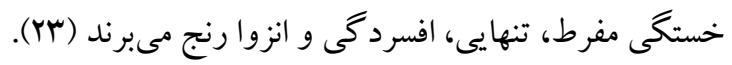

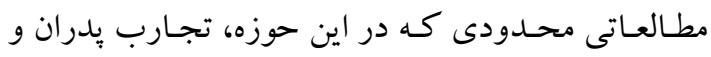
مادران را به تفكيك،، كزارش كردهاند بر اين موضــوع تاكيد

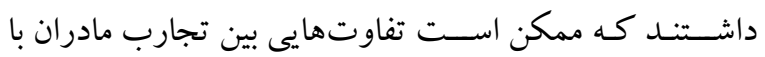

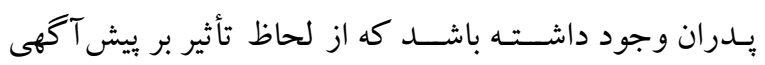

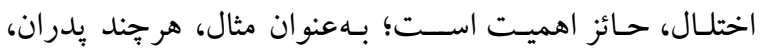
تجارب مثبى مانند اميدوارى يا ابداع و بكار گيرى راهبردهايى آنس براى مديريت مسـائل را نيز گزارش كردهاند (1) (I)، اما مادران

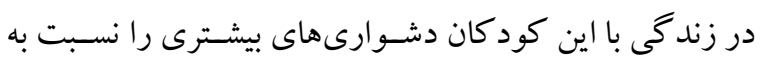
يدران تجربه مى كنند؛ خصوصاً روابط مادران با سايرين شديداً

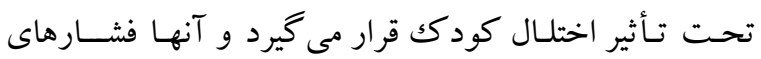

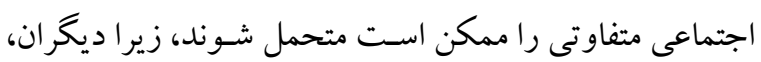
مادر را مسـئول رفتار هاى كودك و بهطور ويزٔه، مشـكلات او

مىدانند (10).

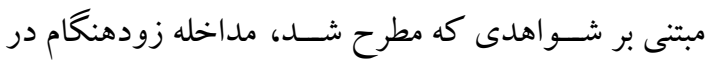
سـنين بيشدبستان ضرورى است و توجه به متغيرهاى مرتبط با مادران براى بهبود بهزيسـتى آنان همجينين افزايش توان بالقوه

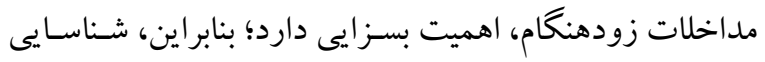
تجـارب مـادران در ســنين ويشدبســتانى مى تواند نيل به اين

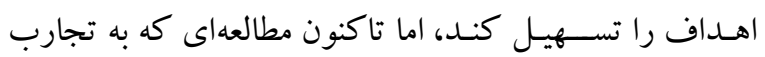
مادران داراى كود كك ييشدبستانى مبتلا به اين اختلال متمر كز شده باشد، صورت نكرفته است. همجينين با وجود تفاوت ميان

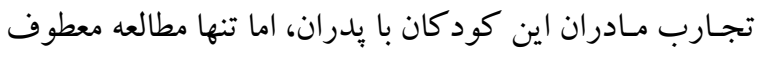

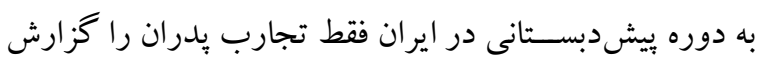

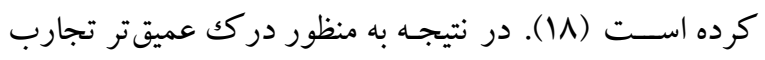

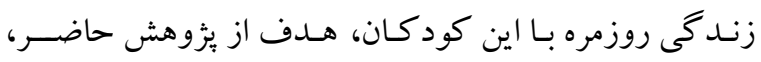

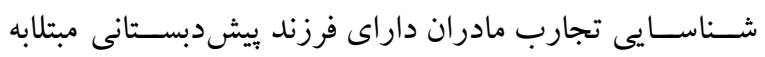
اختلال نارسايى توجه /فزون كنشى بود. 
واحدهاى معنى در متنها مشــص شــــ. معانى عبارات مهم،

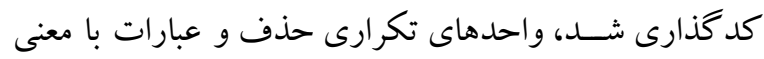

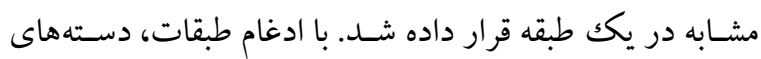

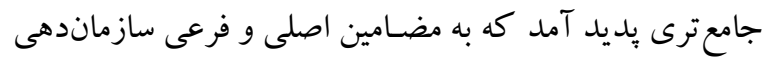

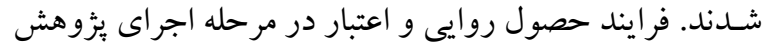
بـدين صـورت انجام گرفت كه: الف) قابليت اجرا با انتخاب شـركت كنند گان از دامنه فرهنكى -اجتماعى گستر ده صورت

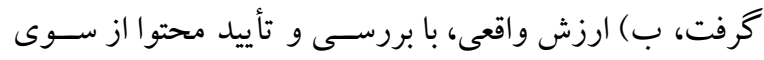

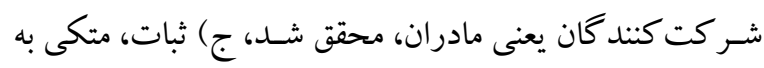

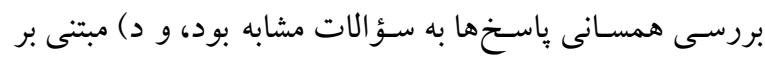
واقعيت بودن نيز با نخهدارى مســندات مربوط به مصساحبه ها

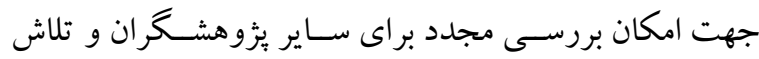

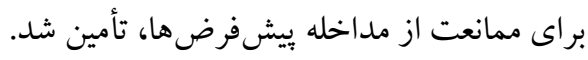

\section{يافتهها}

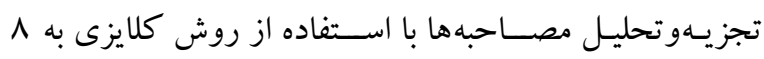

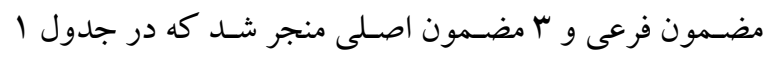
نشان داده شده است.

\begin{tabular}{|c|c|}
\hline مضامين فرعى & مضامين اصلى \\
\hline نآشنايى با تشخيص & \multirow{3}{*}{ نابسندگى دانش و آكاهى } \\
\hline عدم دسترسى به منابع علمى & \\
\hline ف در دانش ضرورى و كاربردى & \\
\hline محدوديتهاى نظام درمان & \multirow{2}{*}{ دشوارىهاى درمان } \\
\hline كشاكش با دارودرمانى & \\
\hline تنش و تعارض & \multirow{3}{*}{ مشكلات تعامل در شبكه روابط } \\
\hline كناه و شرم & \\
\hline تنهايى و انزوا & \\
\hline
\end{tabular}

\section{مضمون اصلى ا: نابسند إنى دانش و آكاهى}

اين مضـمون، مفاهيم مرتبط با اطلاعات مادران در زمينه اختلال را شـامل مىشـود و نياز آنان به دانش متناسب و قابل اعتماد را

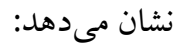

سن، تحصيلـات، تعـداد فرزندان، شــل و نظاير آن بود، و r) مصاحبه، كه در يُوهش حاضر مصاحبه عميق و بدون ساختار به كار رفت، زيرا به دليل انعطاف يذيرى اين نوع از مصاحبهها، متناسـب با بثزوهش كيفى و روى آورد بديدارشـناختى هستيتند.

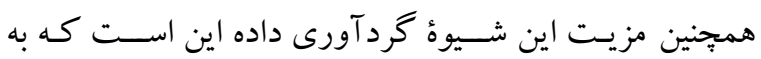

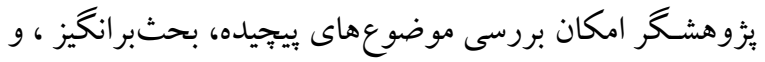
كثــمكشبر انخيز را مىدهـد. بـهـور كلى، روايى و اعتبـار دادهـاى حـاصـل از طريق بايبندى به معيارهاى قابليت اجرا، ارزش واقعى، ثبـات، و مبتنى بر واقعيـت بودن، در اجراى

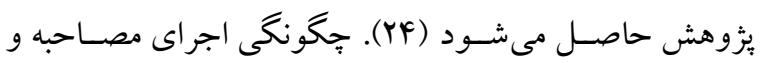
حصول روايى و اعتبار در بخش روش اجرا ارائه شد.

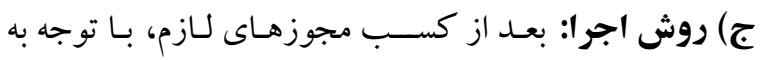
ملاككهاى ورود و خروج همجنين شيوه نمونه گيرى و بر اساس حد اشباع، كه بيش تر توضسيح داده شد، مادران شر كت كننده در مصـاحبهها حضـور يافتند. متوســط سـن مادران در اين يثزوهش MF/D ســال بود و تحصـيلات آنان دامنهاى از ســوم راهنمـايى تا دكترا را شــامل مى شــــ. تعداد فرزندان آنان در

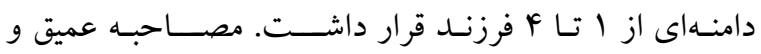
سـاختارنايافته با اين مادران در يكى از اتاقهاى آرام و ايمن

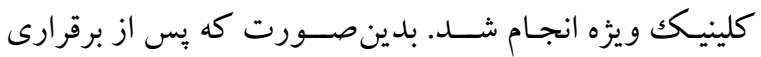

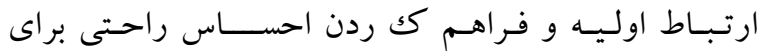
شـركت كنندها، از آنان خواسته مى شد تا به صحبت در مورد يرورش فرزند مبتلابه اختلال نارسـايى توجه/فزون كنشـى خود

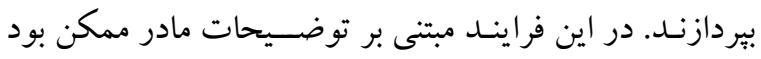
خواسته شود تا در مورد برخى موضوعات توضيحات بيشترى ارائه كند، از احساساتش بكويد، يا آنجه توسط مصاحبه كننده دركك شـده بود مجدد برايش توضسيح داده مىشـد تا تصـريح

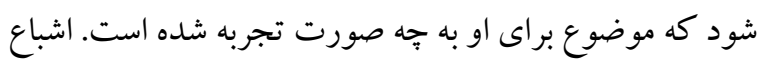

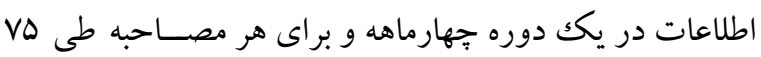

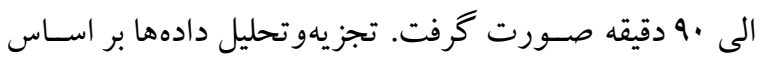
روش كلايزى (YD) بدينصورت بود كه با بيادهسازى و تكرار

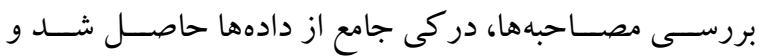


B مطالب بيشتر در مورد بجهه هاى بزركت ترى كه مدرســ

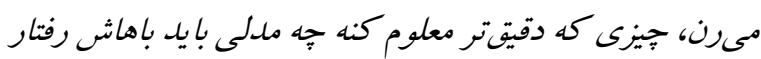

$$
\text { كنم للازم دارم }
$$

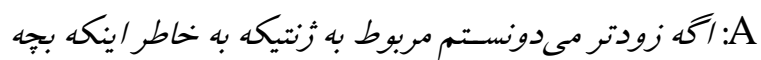

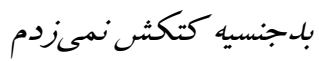

\section{مضمون اصلى זّ: دشوارىهاى درمان}

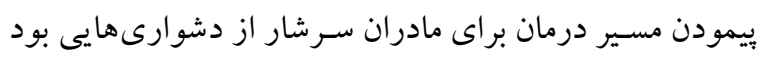
كـه فراينــد مديريت اختلال رابه تجربهاى دشـــوار مبدل كرده

بود:

\section{مضمون فرعى 1: محدوديتهاى نظام درمانى}

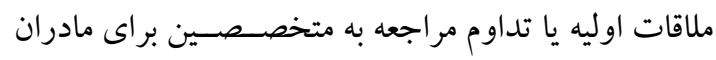

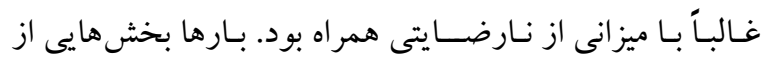

مصاحبه مادران به كمبود متخصصين، مشكلات در نظام ارجاع، عدم دسترسى به مداخله هاى غير دارويى، ناكافى بودن يوشش بيمه و... اختصاص يافته بود. ازنظر آنان جيدمان محيط، هزينه و نوبت گيرى بر رضايت خاطرشان مؤثر بود و تشخيص اختلال،

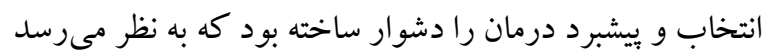

اين موارد به محدوديت هاى نظام درمانى اشاره دارد.

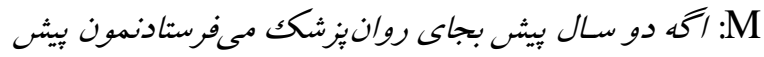
روانيزشك كودكى، خيلى مشكلات اصلًا بيش نميومد.

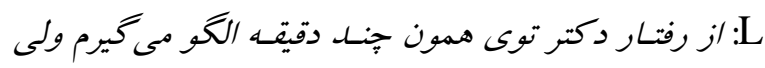

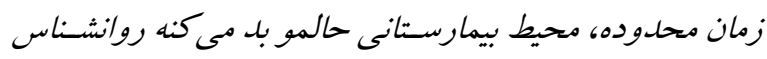

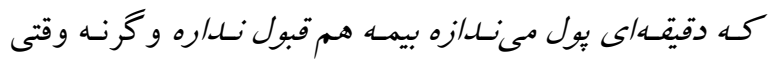
مىرفتم حس خودم بهتر شده بود.

\section{مضمون فرعى r: كشاكش با دارودرمانى}

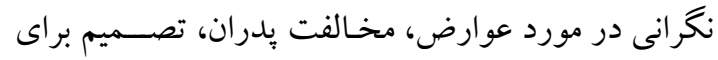

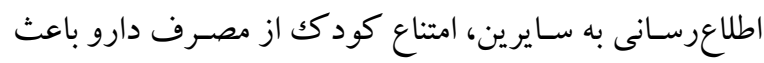
شـد تا مر احل تصـميم گيرى براى مصسرف و تداوم اسـتفاده از دارودرمانى در بيشدبسـتان موضوعى باشد كه با تجربه بيشين بران مادران در استفاده از دارو براى بيمارى هاى جسـمانى كودكك

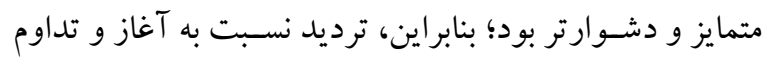

مضمون فرعى ا: نآشنايى با تشخيص بيش از دريافت تشخيص اختلال، مادران وجود تفاوت هايى

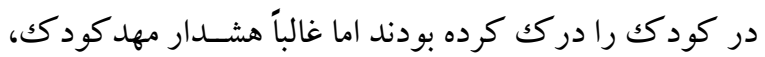
توصسيه آشــنايان آكاه و يا تر كيبى از اين موارد و نه شـناخت

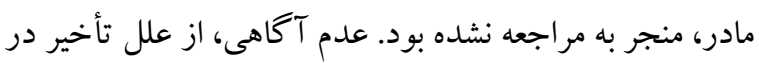

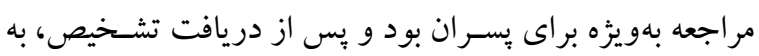

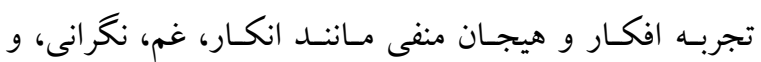
سردر گمى منجر مى شد. فكر نمى كرديم للازم بـاشــه بيارمش دكتر، خيلى بـه هم ريختم، انغار ديخه دنيا براى من تموم شلد.

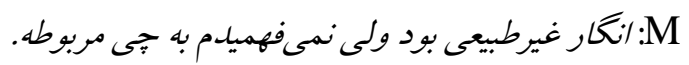
مضمون فرعى ז٪: عدم دسترسى به منابع علمى

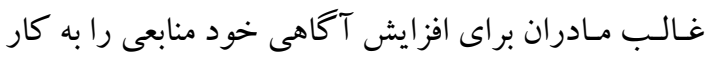

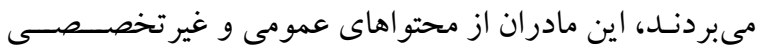

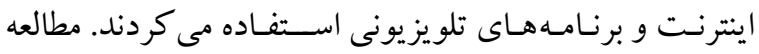

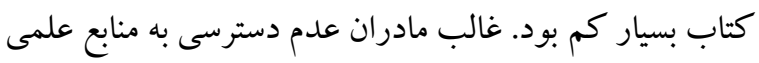

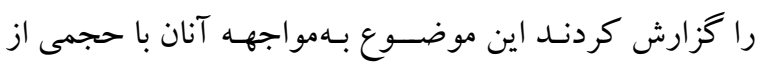
اطلاعات متنوع، غيرعلمى و گاه متضاد منجر شده بوداد

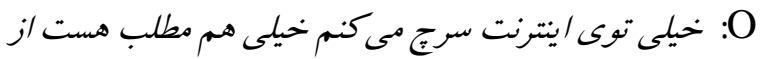

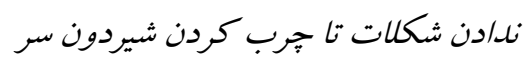
N خوب شلدن بيش فعالى مطلب هست، /ما كيجكننده /ست خيلى وقتا برعكسه

\section{مضمون فرعى "ّ: ضعف در دانش ضرورى و كاربردى}

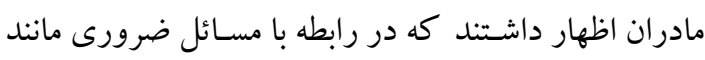

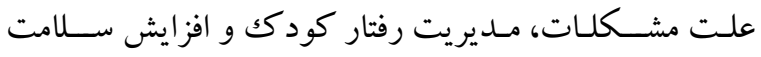
روانشناختى خود جهت ار ائه كمك مؤثر به كود كى، اطلاعات

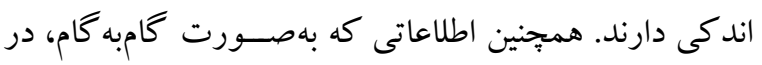

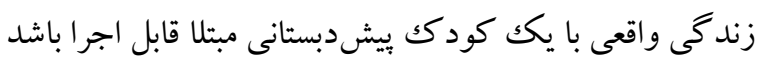
در اختيارشان قرار ندارد. 


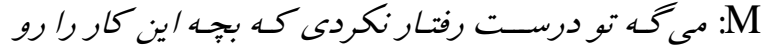

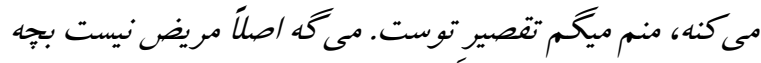

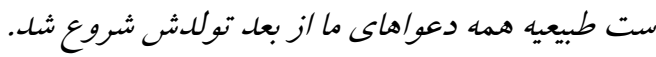

\section{مضمون فرعى r: كناه و شرم}

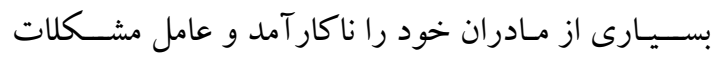
كودك مى داننـد درنتيجه احســاس كناه مى كنند. ديخران نيز آنان را مقصر رفتارهاى كودكك مىدانستيند و به طرق مستقيم (شماتت) يا غير مستقيم (نصيحت) جنين ييامى را به آنان منتقل

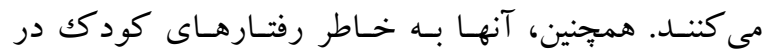
موقعيت هايى مانند مهمانى، خريد و.. احسـاس شـرم را تجربه

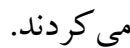

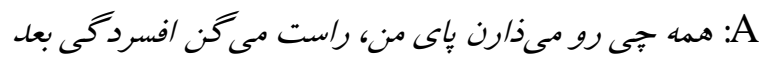
زايمان داشتم، روش اثر د/شته، تقصير منه

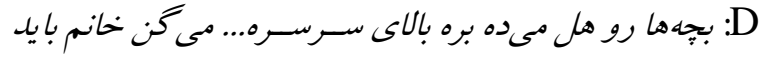

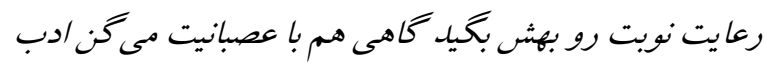

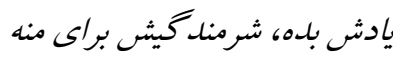

\section{مضمون فرعى بّ: تنهايى و انزوا}

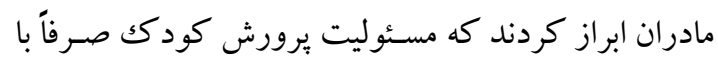

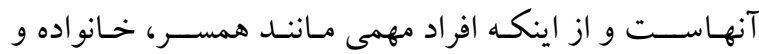
متخصـصـين، در سـطح مورد نظر مادران همكارى نمى كنند

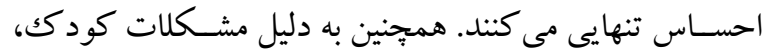
مادران تعاملات خود را محدود ساختهاند يا سايرين از ارتباط با بان مادران امتناع مىورزند، درنتيجه اين مادران در انزوا قرار دارند.

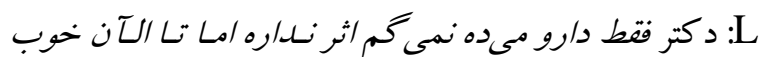

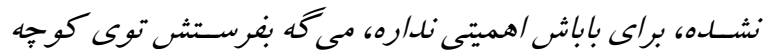

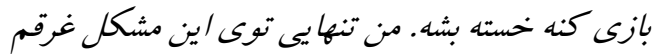

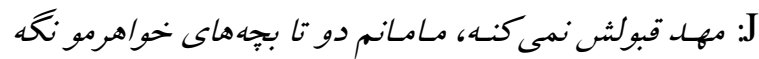
مى داره ولى حاضر نيست / ينو براى يه ساعتم نكه داره.

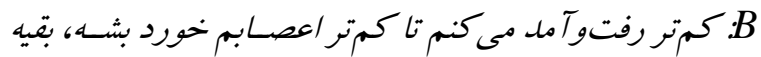
حتى خواهو خودم از رفتاشــون معلومه كه دوستـت ندارن زياد توى جمعشون باشيم
دارودرمـانى حتى براى مـادرانى كـه بـاســـخ فرزنـدشــان بـهـ دارودرمانى مثبت بود، مشاهده شد.

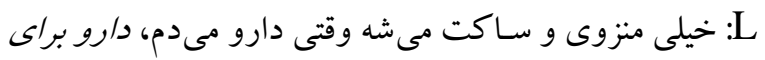

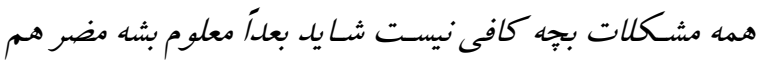
C : الش خودم شكك داشتم بعدش باز باباش مخالف بود الانم

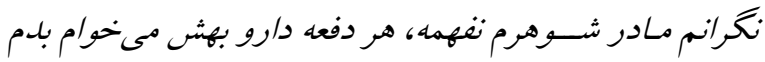
جنگك داريم

\section{مضـمون اصسـلى با: مشـكلات تعامل با شـبكه روابط} اجتماعى تعامل مادران با شبكه روابط اجتماعى بيرامون آنان از بيامدهاى اختلال، مصــون نبود؛ هرجند دلايل متنوعى نيز مطرح شـــــ اما تمـامى مـادران ابراز كردند كه رفتارهاى كودكك مبتلا منجر به ايجـاد يا وخامت تجربه هيجانات منفى و تعارض ها در خانواده

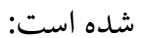

\section{مضمون فرعى ا: تنش و تعارض}

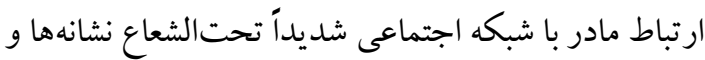
بيامدهاى اختلال نارسايى توجه/فزون كنشى قرار داشت. ارتباط

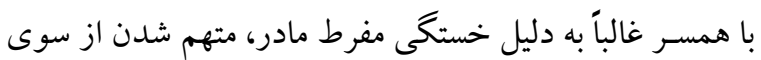
يدر يا حتى مقصـر دانستن بدر، با تنش و تعارض آميخته بود.

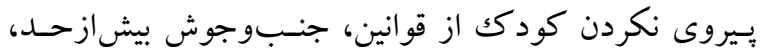
سـاعات خواب نامنظم يا در گيرى با همســالان، منجر به ايجاد

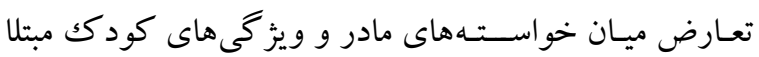
مى شد. همجنين تقاضاهاى مضاعف كود ك، مانند نياز بيشتر به نظارت و مر اقبت، باعث مى شد تعامل مادران با ساير فرزندان محدود شـــه و تنش ها شـــت بيابد. تعدادى از مادران ابراز

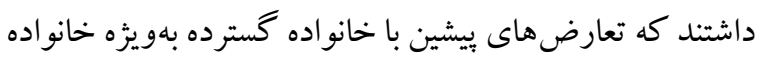

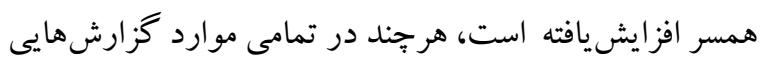
مبنى بر همراهى همســر، فرزنــان و اقوام وجود داشــت امـا بهور كلى مشكلات مطرحشده، تجربه غالب مادران بود.

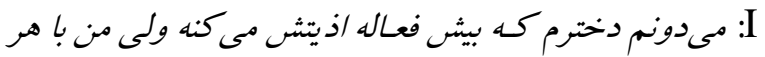
دو دعوا مىكنم. رابطه من با هر دو شون خرابه 
عوارض داروهـا در بيشدبســـان و همجنين ترديد و نكرانى والدين در مورد دارودرمانى موضــوع رايجى اســت كه مانع

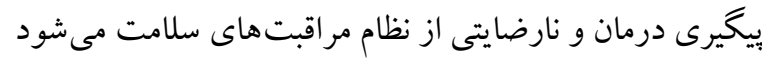
( (r، هو • (1). در نتيجه اين مضمون، همسو با ئزوهشهاى بيشين

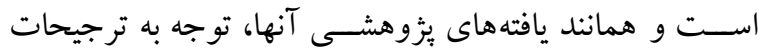

والدين در تصميمات بالينى را برجسته مىسازد (آو 11).

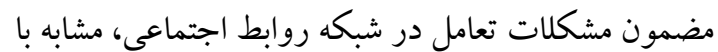

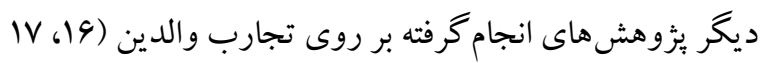
و ·r) و نتايج فراتحليل اين تجارب (هاب (1) وجود دشـوارى در

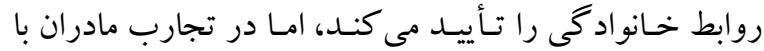

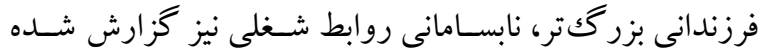

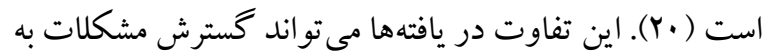
سـاير حوزهها را با افزايش سـن كودكى را نشــان دهد (سبا).

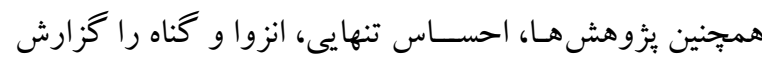
كرده و نسـبت به تأثيرات آن بر سـلامت روان مادران هشــــار مىدهند (1)، 19 و •Y)، با اين وجود تفاوت در مصــداقهايى كه به استخراج اين مضامين منتج شد، سهم احتمالى مؤلفه هاى فرهنگ را برجسته مى سازد. بهطور كلى اين يافتهها، ضـرورت حمايت تخصسصسى از مادران، طى نخستين سالهاى تحول اختلال را نشان مىدهد و هر يكك از مضامين حاصل را بهعنوان يكك هدف درمانى بالقوه معرفى مى كند كه بايد براى بهبود نتايج درمانى مورد نظر قرار

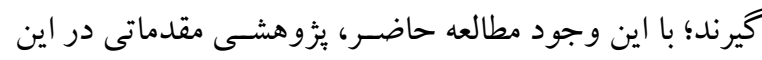
حوزه بود كه فقدان يزوهش كيفى مشابه، براى مقايسه دقيقتر

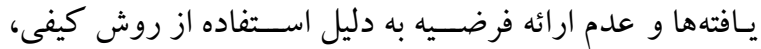
محدوديت هاى عمده اين يُزوهش محسوب مى شوند. در نتيجه ييشــهاد مىشـود يثزوهش هاى آتى به شـناسايى ساير متغيرهاى

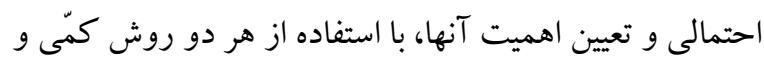

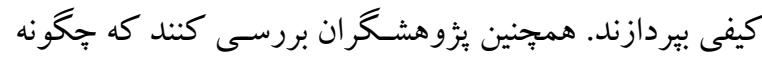
بايد به نيازهاى مادران يرداخت و صلاحيت متخصصان در اين حوزه را بهبود بخشـيد تا به كاهش بيامدهاى اختلال براى مادر و كودك منجر شود.
A مادر شــوهرم رســماً كفت ما نامزدى دير بيايم جون بجهه مجلسو به هم مىزند.

بحث و نتيجه كيرى

هدف بثزوهش حاضــر، شـــاسـايى تجارب مادران كودكان ييش دبسـتانى مبتلابه اختلال نارسـايى توجه/فزون كنشى بود كه بدين منظور، از روش كيفى با روى آورد بديدارشناسى در اين

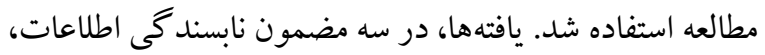

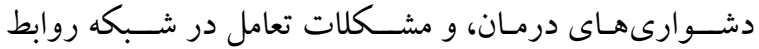
اجتماعى، سـازماندهى شـدند. شـايان توجه است كه يافتههاى اين يثوهش، مشابه با مطالعات ييشين، يرورش فرزند مبتلابه اين

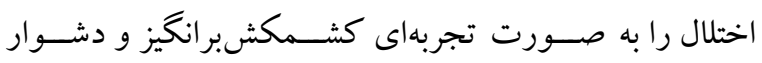
توصسيف كرد (N، 9 و و IV)، امـا بـه دليـل تمركز بر بـازه بيشدبســان، تكميل كننده ســاير يزوهش هاى كيفى در اين

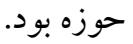

طى مقـايسـهـ يـافتهـهـاى اين بزوهش بـا ديكر مطـالعـات

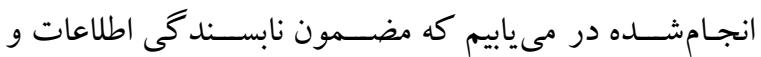

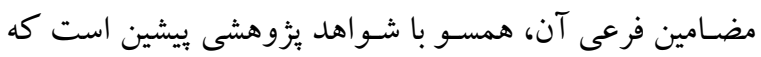

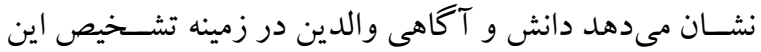
اختلال، با محدوديت عمدهاى مواجه اسـت (N| و Y Y) كه اين

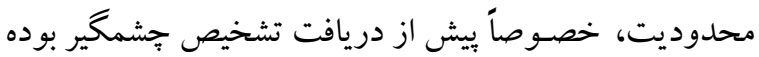
است (Y) (Y)؛ بنابر اين، مطالعه حاضر همانند يزوهش هاى كمى و كيفى انجام گر فته در اين حوزه، دشوارى دسترسى به اطلاعات

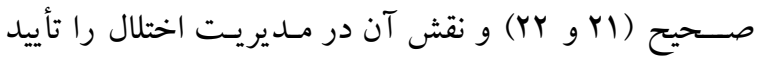
مى كنند (·1، ساو (19)

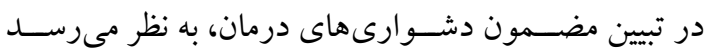

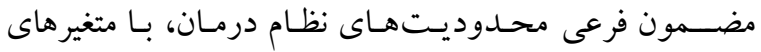

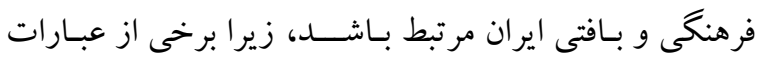

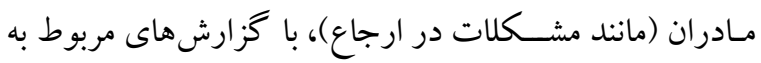
شـكاف در ارائه خدمات سـلامت روان براى كود كان ايرانى، همخوانى دارد (V). كشــمكش بـا دارودرمانى نيز مورد تأييد شـواهد يُزوهشى متعدد كيفى و كمّى است (1))؛ شيوع بالاتر 
وابستهنه به دانشــاه علوم بزشـكى مشـهـد و شـر كت كنند كان در اين مطالعه تشكر قدردانى مىشود.

تضـاد منافع: اين يُزوش براى نويسند كان هيج گونه تضاد منافع به دنبال نداشته است.
تشــكر و قـدردانىى: اين بزروهش بر گرفتـه از بـايان نامه دكتراى تخصـصى زهرا حسـينزاده ملكى در رشـته روانشـناسى دانشـاه

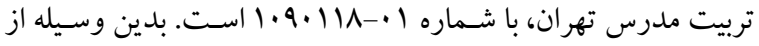

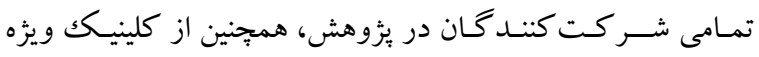
بيمارستان آموزشى تخصصى و فوق تخصصى روانيز شكى ابنسينا 


\section{References}

1. Canals J, Morales-Hidalgo P, Jané MC, Domènech E. ADHD prevalence in Spanish preschoolers: comorbidity, socio-demographic factors, and functional consequences. J Atten Disord. 2018; 22(2): 143153. [Link]

2. Sayal K, Prasad V, Daley D, Ford T, Coghill D. ADHD in children and young people: prevalence, care pathways, and service provision. Lancet Psychiatry. 2018. 5(2): 175-186. [Link]

3. Sonuga-Barke EJS, Barton J, Daley D, Hutchings J, Maishman T, Raftery J, et al. A comparison of the clinical effectiveness and cost of specialised individually delivered parent training for preschool attention-deficit/hyperactivity disorder and a generic, group-based programme: a multi-centre, randomised controlled trial of the New Forest Parenting Programme versus Incredible Years. Eur Child Adolesc Psychiatry. 2018; 27(6): 797-809. [Link]

4. Hosainzadeh Maleki Z, Mashhadi A, Soltanifar A, Moharreri F, Ghanaei Ghamanabad A. Barkley's parent training program, working memory training and their combination for children with ADHD: attention deficit hyperactivity disorder. Iran J Psychiatry. 2014; 9(2): 47-54. [Link]

5. Sonuga-Barke EJS, Brandeis D, Cortese S, Daley D, Ferrin M, Holtmann M, et al. Nonpharmacological interventions for ADHD: systematic review and meta-analyses of randomized controlled trials of dietary and psychological treatments. Am J Psychiatry. 2013; 170(3): 275-289. [Link]

6. Chacko A, Wymbs BT, Rajwan E, Wymbs F, Feirsen N. Characteristics of parents of children with adhd who never attend, drop out, and complete behavioral parent training. J Child Fam Stud. 2017; 26(3): 950-960. [Link]

7. Sharifi V, Mojtabai R, Shahrivar Z, Alaghband-Rad J, Zarafshan H, Wissow L. Child and Adolescent Mental Health Care in Iran: Current Status and Future Directions. Arch Iran Med. 2016; 19(11): 797804. [Link]

8. Moen ØL, Hall-Lord ML, Hedelin B. Contending and adapting every day: Norwegian parents' lived experience of having a child with ADHD. J Fam Nurs. 2011; 17(4): 441-462. [Link]

9. Ho S-WC, Chien WT, Wang L-Q. Parents' perceptions of care-giving to a child with attention deficit hyperactivity disorder: an exploratory study. Contemp Nurse. 2011; 40(1): 41-56. [Link]

10. Ahmed R, McCaffery KJ, Aslani P. Factors influencing parental decision making about stimulant treatment for attention-deficit/hyperactivity disorder. J Child Adolesc Psychopharmacol. 2013; 23(3): 163-178. [Link]

11. Laugesen B, Lauritsen MB, Jørgensen R, Sørensen EE, Grønkjær M, Rasmussen P. ADHD and everyday life: healthcare as a significant lifeline. J Pediatr Nurs. 2017; 35: 105-112. [Link]

12. Ershad Sarabi R, Hashemi Razini H, Abdollahi MH. Comparing parental stress, parenting styles, and social problem solving in mothers of children with autism spectrum disorder, ADHD, and typically developing children. Quarterly Journal of Child Mental Health. 2018; 4(4): 165-179. [Persian]. [Link]

13. Beh-Pajooh A, Parand A, Emami N, Seyyed Noori SZ. Comparison of academic achievement in elementary students with and without attention deficit / hyperactivity disorder (ADHD). Quarterly Journal of Child Mental Health. 2016; 3(2): 31-39. [Persian]. [Link]

14. Wong IYT, Hawes DJ, Clarke S, Kohn MR, Dar-Nimrod I. Perceptions of ADHD among diagnosed children and their parents: a systematic review using the common-sense model of illness representations. Clin Child Fam Psychol Rev. 2018; 21(1): 57-93. [Link]

15. Laugesen B, Groenkjaer M. Parenting experiences of living with a child with attention deficit hyperactivity disorder: a systematic review of qualitative evidence. JBI Database System Rev Implement Rep. 2015; 13(11): 169-234. [Link]

16. Davis CC, Claudius M, Palinkas LA, Wong JB, Leslie LK. Putting families in the center: family perspectives on decision making and ADHD and implications for ADHD care. J Atten Disord. 2012; 16(8): 675-684. [Link]

17. Moen $\varnothing \mathrm{L}$, Hall-Lord ML, Hedelin B. Living in a family with a child with attention deficit hyperactivity disorder: A phenomenographic study. J Clin Nurs. 2014; 23(21-22) :3166-3176. [Link] 
18. Hossainzadeh Maleki Z, Rasoolzadeh Tabatbaei K, Mashhadi A, Moharreri F. Preschool children with attention deficit hyperactivity disorder: Iranian fathers' experiences. Journal of Fundamentals of Mental Health. 2018; 20(4): 283-293. [Persian]. [Link]

19. DosReis S, Barksdale CL, Sherman A, Maloney K, Charach A. Stigmatizing experiences of parents of children with a new diagnosis of ADHD. Psychiatr Serv. 2010; 61(8): 811-816. [Link]

20. Gharibi H, Gholizadeh Z. Phenomenology of mothers' experiences in living with children with AD/HD disorder. Procedia Soc Behav Sci. 2011; 30: 1630-1634. [Link]

21. Ahmed R, Borst JM, Yong CW, Aslani P. Do parents of children with attention-deficit/hyperactivity disorder (ADHD) receive adequate information about the disorder and its treatments? A qualitative investigation. Patient Prefer Adherence. 2014; 8: 661-670. [Link]

22. Moldavsky M, Sayal K. Knowledge and attitudes about attention-deficit/hyperactivity disorder (ADHD) and its treatment: the views of children, adolescents, parents, teachers and healthcare professionals. Curr Psychiatry Rep. 2013; 15(8): 377. [Link]

23. Corcoran J. Parents' experience of raising a child with attention deficit disorder. ADHD Rep. 2017; 25(4): 6-10. [Link]

24. Holloway I, Galvin K. Qualitative research in nursing and healthcare. 4th ed. John Wiley \& Sons; 2016, pp:51. [Link]

25. Colaizzi PF. Psychological research as the phenomenologist views it. In: Valle RS, King M, editors. Existential-Phenomenological alternatives for psychology. New York, NY, US: Oxford University Press; 1978, pp: 6. [Link] 